\title{
Study of Genetic Variability, Heritability and Genetic Advance in Sesame (Sesamum indicum L.) Genotypes
}

\author{
Tushar Arun Mohanty*, Umesh Kumar Singh, Satish Kumar Singh², \\ Nitesh Kushwaha ${ }^{3}$ and Digvijay Singh $^{4}$
}

\author{
Department of Plant Breeding and Genetics, Dr. Rajendra Prasad Central Agricultural \\ University, Pusa, Samastipur, Bihar-848125, India
}

*Corresponding author

\section{Keywords}

Sesame, Genetic variability,

Heritability,

Genetic advance

Article Info

Accepted:

05 January 2020

Available Online:

10 February 2020

\section{A B S T R A C T}

The investigation was carried out to access the analysis of variance, genetic variability, heritability and genetic advance with 30 genotypes including a check namely Krishna. The genotypes were grown in randomised block design with three replications during Kharif 2018 at research farm of Tirhut College of Agriculture, Dholi. Analysis of variance revealed highly significant variation among the genotypes for all the characters. The variability study indicated high to moderate phenotypic and genotypic coefficient of variation accompanied by high heritability and high to moderate genetic advance as per cent of mean for traits like plant height $(\mathrm{cm})$, days to first flowering, days to $50 \%$ flowering, days to maturity, number of productive branches/plant, height of $1^{\text {st }}$ capsule $(\mathrm{cm})$, number of productive capsules per plant, number of seeds per capsule, biological yield per plant, harvest index(\%), 1000 seed weight $(\mathrm{g})$, stearic $\operatorname{acid}(\%)$, linolenic $\operatorname{acid}(\%)$, linoleic acid(\%), oleic acid(\%), palmitic acid(\%), oil content (\%),oil yield per plant $(\mathrm{g})$ and seed yield per plant $(\mathrm{g})$. This study indicates preponderance of additive gene effect, which will help to make selection in early segregating generation. The genetic advance as per cent mean suggesting still there is scope for further improvement of genotypes for these characters. Therefore, these characters can be considered as a criterion for improving seed yield in breeding programs of sesame.

\section{Introduction}

Sesame (Sesamum indicum L.) is one of the prehistoric oilseed crop, dates back to 3050$3500 \mathrm{BC}$ and has been cultivated from ancient times, (Bedigian and Harlan, 1986). It is extensively cultivated worldwide and naturalized in dry habitats of tropical and subtropical regions of the old world, the major sesame producing regions of world 
belongs to the developing nations of Asia and Africa i.e. Myanmar, India, China, Sudan, Ethiopia, Uganda, and Nigeria. It is generally known as gingelly, til, benniseed and simsin in different parts of the world (Prajapat et al., 2014).

India holds a premier position in the global oilseeds scenario accounting for 29 per cent of the total area and 26 per cent of production. Globally, China and India are the major sesame producers. Rajasthan, Gujarat, Madhya Pradesh, Andhra Pradesh, West Bengal and Tamil Nadu put together constitutes nearly 72 per cent of total area and 58 per cent of total production of sesame in the country.

Sesame is designated as the "Queen of oilseed crops" because of its high nutritive quality (rich in carbohydrate, protein, calcium, iron and phosphorous) and quantity of oil (40 to63\%).

Sesame oil has highest antioxidant content and contains several fatty acids such as oleic acid (43\%), linoleic acid (35\%), palmitic acid $(11 \%)$ and stearic acid (7\%) and stablility against oxidative raincidity owing to the occurrence of the natural antioxidants namely, lignans (sesamin, sesamolin and sesamol), and $\gamma$-tocopherol, which offers long shelf life to the sesame oil (Ashri, 1989; Anilakumar et al., 2010).

Sesame has a relatively superior oil quantity as well as quality in comparison to many major oil crops. Sesame is a plant breeder's dream because it has high variability. The presence of variability in crop is important for genetic studies and consequently used for improvement and selection. Assessment of variability forms the basis for any crop improvement programme.

A study of the manner in which a particular character behaves in relation to others contributing to seed yield will be great significance in planning successful breeding strategies in any crop improvement programme. Yield being a complex character is influenced by various component characters, which are polygenetically inherited and highly subjected to environmental variation.

More emphasis, therefore, needs to be placed on the selection of yield attributes which are less influenced by the environment. Besides, genotypic and phenotypic coefficient of variation, heritability and genetic advance, a study of correlation among yield and its components and their relative contribution to yield is of great value in the breeding programmes.

\section{Materials and Methods}

A field experiment for present investigation was conducted during Kharif 2018 under rainfed condition on the Research Farm of Tirhut College of Agriculture, Dholi, Muzaffarpur, Bihar. The field selected for experiment is uniform with typical medium soil having medium fertility and fairly good drainage.

Agro climatically University Farm is situated between $25.980 \mathrm{~N}$ latitude and $85.670 \mathrm{E}$ longitudes at $51.8 \mathrm{~m}$ above mean sea level. The experimental material consisted of 30 sesame genotypes laid out in a Randomized

Block Design with three replications. Each genotype in each replication was sown in three row plot of $4.0 \mathrm{~m}$ length, adopting a spacing of $30 \mathrm{~cm}$ between rows and $20 \mathrm{~cm}$ between the hills. The observations were recorded on plant height $(\mathrm{cm})$, days to first flowering, days to $50 \%$ flowering, days to maturity, number of productive branches per plant, height of $1^{\text {st }}$ capsule $(\mathrm{cm})$, number of 
productive capsules per plant, number of seeds per capsule, biological yield per plant $(\mathrm{g})$, harvest index (\%), 1000 seed weight $(\mathrm{g})$, stearic acid (\%), linolenic acid (\%), linoleic acid (\%), oleic acid (\%), palmitic acid (\%), oil content $(\%)$,oil yield per plant (g) and seed yield per plant $(\mathrm{g})$. The data were subjected to statistical analysis

\section{Statistical analysis}

Mean values of the characters for each genotype per replication were used for analysis of variance as per methodology advocated by Panse and Sukhatme (1967). Heritability in broad sense estimates were calculated according to formula suggested by Johnson et al. (1955) and the estimates of genetic advance were obtained by the formula given by Lush (1949).

\section{Results and Discussion}

In the present investigation, thirty sesame genotypes were studied to assess their performance in terms of traits implicated to yield. The analysis of variance revealed significant difference among the genotypes for all traits viz., plant height $(\mathrm{cm})$, days to first flowering, days to $50 \%$ flowering, days to maturity, no of productive branches/plant, height of 1st capsule $(\mathrm{cm})$, number of productive capsules per plant, number of seeds per capsule, biological yield per plant, harvest index (\%), 1000 seed weight $(\mathrm{g})$, stearic acid (\%), linolenic acid (\%), linoleic acid (\%), oleic acid (\%), palmitic acid (\%), oil content (\%),oil yield per plant (g) and seed yield per plant $(\mathrm{g})$, exhibited highly significant mean sum of square.

This indicates that sufficient variability is present for most of the important characters among different genotypes and thus suggested a substantial scope of selection. This result was in accordance with report of Rao et al.
(2014) days to $50 \%$ flowering, days to maturity, plant height $(\mathrm{cm})$, number of branches per plant, number of capsules per branch, number of seeds per capsule, test weight and seed yield per plant.; Parameshwarappa et al. (2009) for days to $50 \%$ flowering, number of branches per plant, plant height, number of capsules per plant, capsule length, number of seeds per capsule, 1000 -seed weight, seed yield per plant and oil content.

Examination of the components of variance revealed that the phenotypic variances for almost all the traits under studied were higher than the genotypic variances this may be due to the non-genetic factor which played an important role in the manifestation of these characters.

The maximum phenotypic and genotypic variance exhibited by the traits viz., biological yield per plant, number of productive capsules per plant, plant height, number of seeds per capsule, oil content, harvest index. These findings were in accordance of Suvarna et al. (2008), Manjunatha et al. (2008) who also observed high variance for yield and yield component traits among sesame genotypes. The height of $1^{\text {st }}$ capsule exhibited high genotypic variance than phenotypic variance.

Coefficient of variation gives the idea about up to what extent variation is present in a population. Estimates of genetic parameters in the present study indicated that the phenotypic coefficient of variation (PCV) were invariably higher than their corresponding genotypic coefficient of variation $(\mathrm{GCV})$ for all the characters with a narrow difference indicates that environmental influence was least and preponderance of genetic factors controlling variability in these traits. High magnitude of PCV and GCV were observed for the traits viz., biological yield per plant, harvest index, 
productive capsules per plant, oil yield per plant, seed yield per plant, linolenic acid and productive branches per plant. Results indicated greater scope for selection of these traits for further breeding work.

Similar results have been reported by Patil and Sheriff (1996) for seed yield per plant, oil yield per plant and number of capsules per plant, Subrata and Maity (1997) for seed yield per plant, number of branches per plant, Babu et al. (2004) for oil yield per plant and seed yield per plant, Sumathi and Muralidharan (2010) for number of branches per plant, number of capsules per plant and seed yield per plant, Gidey et al. (2013) for harvest index and seed yield per plant, Hika et al. (2015) for biological yield per plant, Kiruthika et al. (2018) for number of capsules per plant and oil content.

Moderate values of PCV were noticed for characters viz., height of $1^{\text {st }}$ capsule, plant height, number of seeds per capsule, oil content and 1000 seed weight. Similar results have been recorded by Tripathi et al. (2013), Vanishree et al. (2013), Ahadu (2012), Sumathi and Murlidharan (2010) and Parameshwarappa et al. (2009) for plant height, Gangadhara et al. (2012) for 1000seed weight and number of seeds per capsule.

Low values of PCV were noticed for stearic acid, days to first flowering, days to $50 \%$ flowering, palmitic acid, oleic acid, linoleic acid and days to maturity. Similar results have been reported by Tripathi et al. (2013), Vanishree et al. (2013), Parameshwarappa et al. (2009) and Sudhakar et al. (2007) for days to maturity, Chandra Mohan (2014) and Thirumalarao (2013) for days to $50 \%$ flowering.

Heritability plays a vital role in deciding the suitability and strategy for selection of a particular character. The highest heritability was exhibited by linolenic acid followed by oil content, biological yield per plant, number of productive capsules per plant, stearic acid, palmitic acid, days to $50 \%$ flowering, harvest index, days to first flowering, oil yield per plant, seed yield per plant, oleic acid, height of $1^{\text {st }}$ capsule, linoleic acid, number of productive branches per plant, plant height, number of seeds per capsule.

Medium heritability was recorded for Days to maturity and 1000 seed weight. Similar results have been obtained by Desawi et al. (2014), Rani (2014), Vanishree et al. (2013), Shekhawat et al. (2013) and Gangadhara et al. (2012) for no of productive capsules per plant, Abate and Mekbib (2015), Desawi et al. (2014), Tripathi et al. (2013), Gidey et al. (2013), Gangarde et al. (2009), Sudhakar et al. (2007) for days to 50\% flowering, Bindu et al. (2014) and Sudhakar et al. (2007), for oil content, Tamina Begum and Dasgupta (2003) for seed yield, number of capsules per plant, number of branches per plant and plant height, Alake et al. (2010) reported for height of $1^{\text {st }}$ capsule.

Heritability estimates would be reliable if accompanied by a high estimated genetic advance. High heritability coupled with high genetic advance was exhibited by linolenic acid followed by oil content, biological yield per plant, and number of productive capsules per plant, harvest index, seed yield per plant, height of $1^{\text {st }}$ capsule and plant height. Hence these traits might be governed by additive genes; indicating that direct selection would be effective from present genotypes.

These results were in accordance with the findings of Vanishree et al. (2013), Shekhawat et al. (2013), Gangadhara et al. (2012) for number of productive capsules per plant.; Anil Kumar (1999) and Velu and Shunmugavalli (2005) for number of capsules per plant and seed yield per plant. High 
heritability coupled with moderate genetic advance was recorded for stearic acid, days to $50 \%$ flowering, days to first flowering and number of seeds per capsule suggesting that there is a effect of additive and non-additive gene action. Similar results were reported by Gangadhara et al. (2012), Gidey et al. (2012),
Tripathi et al. (2013) and Abate and Mekbib (2015) for days to 50\% flowering. Palmitic acid, oleic acid and linoleic acid were high heritability coupled with low genetic advance as per cent of mean indicating presence of non-additive gene action.

Table.1 Analysis of variance (ANOVA) for design of experiment for nineteen quantitative characters of sesame

\begin{tabular}{|c|c|c|c|c|}
\hline \multirow{2}{*}{$\begin{array}{l}\text { SL } \\
\text { NO. }\end{array}$} & \multirow{2}{*}{ Characters } & \multicolumn{3}{|c|}{ Mean sum of square } \\
\hline & & $\begin{array}{l}\text { Replication } \\
\quad(\mathbf{d f}=2)\end{array}$ & $\begin{array}{l}\text { Treatment } \\
(\mathbf{d f}=29)\end{array}$ & $\begin{array}{c}\text { Error } \\
(d f=58)\end{array}$ \\
\hline 1 & Plant height $(\mathrm{cm})$ & 576.68 & $1946.37 * *$ & 191.52 \\
\hline 2 & Days to first flowering & 0.14 & $44.16^{* *}$ & 1.45 \\
\hline 3 & Days to $50 \%$ flowering & 0.13 & $51.45^{* *}$ & 1.39 \\
\hline 4 & Days to maturity & 5.67 & $17.58 * *$ & 3.52 \\
\hline 5 & $\begin{array}{l}\text { No of Productive Branches per } \\
\text { Plant }\end{array}$ & 0.04 & $5.89^{* *}$ & 0.52 \\
\hline 6 & Height of $1^{\text {st }}$ capsule $(\mathrm{cm})$ & 36.27 & $917.91 * *$ & 59.60 \\
\hline 7 & $\begin{array}{l}\text { No of productive capsules per } \\
\text { plant }\end{array}$ & 48.14 & $4890.66^{* *}$ & 67.69 \\
\hline 8 & No of seeds per capsule & 35.23 & $233.93 * *$ & 41.71 \\
\hline 9 & Biological yield per plant (g) & 248.10 & $14875.70 * *$ & 112.78 \\
\hline 10 & Harvest index (\%) & 0.37 & $71.61 * *$ & 2.16 \\
\hline 11 & 1000 seed weight $(\mathrm{g})$ & 0.04 & $0.46 * *$ & 0.09 \\
\hline 12 & Stearic acid $(\%)$ & 0.01 & $0.54 * *$ & 0.006 \\
\hline 13 & Linolenic acid (\%) & 0.00 & $0.03 * *$ & 0.00 \\
\hline 14 & Linoleic acid (\%) & 1.04 & $6.52 * *$ & 0.46 \\
\hline 15 & Oleic acid $(\%)$ & 0.11 & $7.97 * *$ & 0.34 \\
\hline 16 & Palmitic acid (\%) & 0,03 & $0,48 * *$ & 0,01 \\
\hline 17 & Oil content $(\%)$ & 0.47 & $92.90^{* *}$ & 0.30 \\
\hline 18 & Oil yield per plant (\%) & 0.72 & $40.30 * *$ & 1.76 \\
\hline 19 & Seed yield per plant $(\mathrm{g})$ & 0.02 & $6.37 * *$ & 0.25 \\
\hline
\end{tabular}

** Significant at $\mathrm{P}=0.01$ 
Table.2 Range and mean performance for nineteen different quantitative characters in sesame

\begin{tabular}{|c|c|c|c|c|}
\hline \multirow{2}{*}{$\begin{array}{l}\text { SL. } \\
\text { No. }\end{array}$} & \multirow[b]{2}{*}{ Characters } & \multicolumn{2}{|c|}{ Range } & \multirow[t]{2}{*}{ MEAN } \\
\hline & & Min & Max & \\
\hline 1 & Plant height $(\mathrm{cm})$ & 109.66 & 225.16 & 171.35 \\
\hline 2 & Days to first flowering & 39.33 & 55.66 & 46.00 \\
\hline 3 & Days to $50 \%$ flowering & 42.00 & 60.33 & 52.00 \\
\hline 4 & Days to maturity & 92.66 & 101.66 & 97.00 \\
\hline 5 & No of Productive Branches per Plant & 4.33 & 10.00 & 6.67 \\
\hline 6 & Height of $1^{\text {st }}$ capsule $(\mathrm{cm})$ & 85.13 & 154.00 & 110.02 \\
\hline 7 & No of productive capsules per plant & 67.33 & 271.33 & 120.97 \\
\hline 8 & No of seeds per capsule & 52.00 & 95.33 & 65.66 \\
\hline 9 & Biological yield per plant (g) & 46.11 & 369.83 & 136.52 \\
\hline 10 & Harvest index $(\%)$ & 4.72 & 26.98 & 11.20 \\
\hline 11 & 1000 seed weight(g) & 2.66 & 4.46 & 3.59 \\
\hline 12 & Stearic acid $(\%)$ & 3.56 & 5.36 & 4.63 \\
\hline 13 & Linolenic acid (\%) & 0.28 & 0.85 & 0.40 \\
\hline 14 & Linoleic acid (\%) & 39.94 & 47.41 & 43.87 \\
\hline 15 & Oleic acid $(\%)$ & 38.65 & 45.69 & 41.71 \\
\hline 16 & Palmitic acid (\%) & 8.62 & 10.40 & 9.36 \\
\hline 17 & Oil content $(\%)$ & 25.00 & 47.11 & 36.15 \\
\hline 18 & Oil yield per plant (\%) & 7.63 & 20.98 & 4.70 \\
\hline 19 & Seed yield per plant $(\mathrm{g})$ & 2.26 & 7.61 & 13.01 \\
\hline
\end{tabular}


Table.3 Genotypic $\left(\sigma_{\mathrm{g}}^{2}\right)$ and phenotypic $\left(\sigma_{\mathrm{p}}^{2}\right)$ variance and other genetic parameter for nineteen different quantitative characters in sesame

\begin{tabular}{|c|c|c|c|c|c|c|c|c|}
\hline $\begin{array}{l}\text { Sl. } \\
\text { No. }\end{array}$ & Characters & $\begin{array}{c}\text { Genotypic } \\
\text { variance } \\
\left(\sigma_{g}^{2}\right)\end{array}$ & $\begin{array}{c}\text { Phenotypic } \\
\text { variance } \\
\left(\sigma_{p}^{2}\right)\end{array}$ & GCV(\%) & $\operatorname{PCV}(\%)$ & $\begin{array}{c}\mathbf{h}^{2} \\
(\mathbf{b s} .) \\
\%\end{array}$ & $\begin{array}{l}\text { Genetic } \\
\text { advance }\end{array}$ & $\begin{array}{c}\text { Genetic } \\
\text { advance as } \\
\% \text { of mean }\end{array}$ \\
\hline 1 & Plant height $(\mathrm{cm})$ & 584.95 & 776.48 & 14.18 & 16.34 & 75 & 43.24 & 25.35 \\
\hline 2 & Days to first flowering & 14.24 & 15.69 & 8.24 & 8.65 & 91 & 7.40 & 16.17 \\
\hline 3 & Days to $50 \%$ flowering & 16.69 & 18.08 & 7.87 & 8.19 & 92 & 8.08 & 15.57 \\
\hline 4 & Days to maturity & 4.68 & 8.21 & 2.32 & 2.96 & 57 & 3.37 & 3.47 \\
\hline 5 & $\begin{array}{l}\text { No of Productive Branches } \\
\text { per Plant }\end{array}$ & 1.79 & 2.32 & 20.03 & 22.79 & 77 & 2.42 & 36.27 \\
\hline 6 & Height of $1^{\text {st }}$ capsule $(\mathrm{cm})$ & 286.11 & 34.70 & 15.26 & 16.78 & 83 & 31.70 & 28.60 \\
\hline 7 & $\begin{array}{l}\text { No of productive capsules } \\
\text { per plant }\end{array}$ & 1607.66 & 1675.35 & 33.14 & 33.83 & 96 & 80.91 & 66.88 \\
\hline 8 & No of seeds per capsule & 64.07 & 105.79 & 12.19 & 15.66 & 60 & 12.83 & 19.54 \\
\hline 9 & Biological yield per plant (g) & 4920.97 & 5033.76 & 51.38 & 51.97 & 97 & 142.88 & 104.65 \\
\hline 10 & Harvest index $(\%)$ & 23.15 & 25.31 & 42.93 & 44.89 & 91 & 9.48 & 84.57 \\
\hline 11 & 1000 seed weight $(\mathrm{g})$ & 0.12 & 0.22 & 9.67 & 13.01 & 55 & 0.53 & 14.81 \\
\hline 12 & Stearic acid $(\%)$ & 0.18 & 0.18 & 9.09 & 9.26 & 96 & 0.85 & 18.41 \\
\hline 13 & Linolenic acid (\%) & 0.01 & 0.01 & 25.81 & 25.93 & 99 & 0.21 & 52.95 \\
\hline 14 & Linoleic acid (\%) & 2.02 & 2.49 & 3.24 & 3.59 & 81 & 2.64 & 6.02 \\
\hline 15 & Oleic acid (\%) & 2.54 & 2.88 & 3.82 & 4.07 & 88 & 3.09 & 7.40 \\
\hline 16 & Palmitic acid (\%) & 0.16 & 0.17 & 4.25 & 4.42 & 93 & 0.79 & 8.43 \\
\hline 17 & Oil content $(\%)$ & 30.87 & 31.17 & 15.37 & 15.44 & 99 & 11.39 & 31.50 \\
\hline 18 & Oil yield per plant (\%) & 12.84 & 14.61 & 27.53 & 29.36 & 88 & 6.92 & 53.16 \\
\hline 19 & Seed yield per plant (g) & 2.04 & 2.30 & 30.34 & 32.19 & 89 & 2.77 & 58.91 \\
\hline
\end{tabular}

Classes of Heritability (\%): High > $60 \%$, Medium 30-60\%, Low < $30 \%$

Classes of Genetic Advance (\%): High $>20 \%$, Medium 10-20\%, Low $<10 \%$

Analysis of variance revealed highly significant differences among the genotypes for all the nineteen parameters, indicating the presence of considerable genetic variation in the experimental material. The phenotypic variance was found higher than the corresponding genotypic variances for all the traits under study.

In the present study, high heritability and genetic advance as \% mean were recorded for linolenic acid while, high PCV, GCV recorded for biological yield per plant this character could be relied upon for selection. Selection of such genotypes based on various quantitative yields attributes leads to genetic improvement in sesame especially for seed yield. In future, such traits may be considered for the development of high yielding with good quality sesame varieties.

\section{Acknowledgments}

The authors are grateful to Department of Plant Breeding and Genetics of Dr. Rajendra Prasad Central Agricultural University, Pusa, Samastipur, Bihar for providing the seeds and all required facilities for conducting the research work. 


\section{References}

Abate, M. and Mekbib, F. (2015). Assesment of genetic variability and character association in Ethiopian low-altitude sesame (Sesamum indicum L.) genotypes. Journal of Advanced Studies in Agricultural, Biological and Environmental Sciences. 2(3): 55-66.

Ahadu, Menzir. (2012). Phenotypic variability, divergence analysis and heritability of characters in sesame (Sesamum indicum L.) genotypes. Nature and Science. 10(10): 155-162.

Alake, C.O., Ojo, D.K., Adebisi, M.A. and Ayo-Vaughan, M.A. (2010). Selection criteria for nigerian sesame (Sesamum indicum L.) genotypes. Journal of Tropical Agriculture. 48(1-2): 49-51.

Anilakumar, K. R., Pal, A., Khanum, F., and Bawa, A. S. (2010). Nutritional, medicinal and industrial uses of Sesame (Sesamum indicum L.) seeds-an overview. Agriculturae Conspectus Scientificus (ACS). 75(4): 159-168.

Anil Kumar, V. (1999). Genetic divergence and character association studies in sesame (Sesamum indicum L.). M.Sc.(Ag.) Thesis submitted to Acharya N.G. Ranga Agricultural University, Andhra Pradesh.

Ashri, A. (1989). Sesame. In: Oil Crops of the World: their breeding and utilization. Eds. G. Robbelen, R. K. Downey \& A. Ashri McGraw Hill, NY.: 375-387.

Babu, J. S., Reddy, C. D. R. and Reddy, N. S. (2004). Character association and path coefficient analysis in a set of white seeded genotypes of sesame (Sesamum indicum L.). Annals of Agri-bio Research. 9(1): 13-18.

Bedigian, D. and Harlan, J. R. (1986). Evidence for cultivation of Sesame in the ancient world. Economic botany. 40(2): 137-154.

Bindu, M.R., Sushamakumari, P., Indira, M.,
Vilasini. T.N., Seeja, S. and Yohannan, A.A. (2014). Genetic variability, heritability and genetic advance for yield and its components in sesame (Sesamum indicum L.). International Journal of Plant Sciences. 9(1): 167169.

Chandra Mohan, Y. (2014). Variability and genetic divergence in sesame (Sesamum indicum L.). International Journal of Applied Biology and Pharmaceutical Technology. 5(3): 222-225.

Desawi, H.T., Sentayehu, A.K. and Daniel, E.G. (2014). Assessment of genetic variability, genetic advance, correlation and path analysis for morphological traits in sesame genotypes. Asian Journal of Agricultural Research. 8(4): 181-197.

Gangadhara, J., Prakash, C., Badiger, B, Shadakshari, T.V., Yathish, K.R. and Rajesh, A.M. (2012). Genetic divergence, genetic advance and heritability in sesame (Sesamum indicum L.). BioInfolet. 9(5): 437-462.

Gangarde, S.A., Bangar, N.D. and Katore, T.D. (2009). Variability, heritability and genetic advance in sesame (Sesamum indicum L.). Journal of Maharashtra Agriculture Universities. 34(2): 147148.

Gidey, Y.T., Kebede, S.A. and Gashawbeza G.T. (2013). Assessment of genetic variability, genetic advance, correlation and path analysis for morphological traits in sesame genotypes International Journal of Plant Breeding and Genetics. 7(1): 21-34

Hika, G., Geleta, N. and Jaleta, Z. (2015). Genetic variability, heritability and genetic advance for the phenotypic traits in sesame (Sesamum indicum L.). Populations from Ethiopia. Science, Technology and Arts Research Journal. 4(1): 20-26. 
Johnson, H.W, Robinson, H.F. and Comstock, R.E. (1955). Genotypic, phenotypic correlations in soybean and their implication in selection. Agronomy Journal. 47: 477- 483.

Kiruthika, S., Narayanan, L.S., Parameswari, C. and Arunachalam, P. (2018). Genetic variability studies for yield and yield components in sesame (Sesamum indicum L.). Electronic Journal of Plant Breeding. 9(4): 1529-1537.

Lush, J.L. (1949). Heritability of quantitative characters in farm animals. Heriditas (suppl.). 35, 256-261.

Manjunatha, V., Suvarna. Manjunath. A., Shankar, M.A. (2008). Genetic variability, association and path coefficient analysis in sesame (Sesamum Indicum L.). Agricultural Science University., Raichur, Green farming. 2(1): 7-10.

Panse, V.G. and Sukhatme, P.V. (1967) "Statistical Methods for Agricultural Workers," 2nd Edition, Indian Council of Agricultural Research, New Delhi.

Parameshwarappa, S.G., Palakshappa, M.G., Salimath, P.M. and Parameshwarappa, K.G. (2009). Studies on genetic variability and character association in germplasm collection of sesame (Sesamum indicum L.). Karnataka Journal of Agricultural Sciences. 22(2): 252-254.

Patil, R.R. and Sheriff, R.A. (1996). Genetic variability, heritability and genetic advance studies to sesame (Sesamum indicum L.). Current Research University of Agricultural Sciences Banglore. 25(2): 94-100.

Prajapat, P. and Kumar, M. (2014). Analysis of genetic diversity in Sesamum genotypes using Randomly Amplified Polymorphic DNA Markers. Trends in Biosciences. 7(17): 2418-2424.

Rani, P.J. (2014). Variability, heritability and genetic advance of yield and yield attributing traits over different environments in sesamum (Sesamum indicum L.). Trends in Biosciences. 7(17): 2402-2404.

Rao, V.T., Bharathi, D., Chandra Mohan, Y., Bhadru, D. and Venkanna, V. (2014). Genetic variability studies in sesame (Sesamum indicum L.). International journal of applied biology and pharmaceutical technology. 5(4): 3133.

Shekhawat, R.S., Rajput, S.S., Meena, S.K. and Singh, B. (2013). Variation and character association in seed yield and related traits in sesame (Sesamum indicum L.). Indian Research Journal of Genetics and Biotechnology. 5(3): 186193.

Subrata. and Maity, S.(1997). Variation and association of different agronomic characters in a collection of sesame (Sesamum indicum L.). Environment and Ecology. 15(3): 629-635.

Sudhakar, N., Sridevi, O. and Salimath, P. (2007). Variability and character association analysis in sesame (Sesamum indicum L.). Journal of Oilseeds Research. 24(1): 56-58.

Sumathi, P. and Muralidharan, V. (2010). Analysis of genetic variability, association and path analysis in the hybrids of sesame (Sesamum indicum L.). Tropical Agricultural Research and Extension. 13(3): 63-67.

Suvarna, Manjunatha, M.H., Manjunath, A., Bharathi, S. and Shankar, M.A. (2008). Genetic variability, correlation and path coefficient analysis in sesame (Sesamum Indicum L.). Crop Research Hisar. 35(1- 2): 99-105.

Tamina, G., Begum, M. and Dasgupta, T. (2003). Character association in sesame (Sesamum indicum L.). Indian Agricultural. 47(3): 253-258. 
Thirumalarao, V., Bharathi, D., Chandramohan, Y., Venkanna, V and Bhadru, D. (2013). Genetic variability and association analysis in sesame (Sesamum indicum L.). Crop Research. 46(1, 2 \& 3): 122-125.

Tripathi. A., Bisen, R., Ravindra, P., Paroha, A.S., Sahu, R. and Ranganatha, A.R.G. (2013). Study on genetic divergence in sesame (Sesamum indicum L.) germplasm based on morphological and quality traits. An International Quarterly Journal of Life Sciences.
8(4): 1387-1391.

Vanishree, Lokesha, R., Goudappagoudra, R. and Chetankumar. NB. (2013). Analysis of genetic variability for yield and its components in sesame (Sesamum indicum L.) International Journal of Plant Sciences. 8(1): 91-93.

Velu, G. and Shunmugavalli, N. (2005). Genetic variation and genotype $\times$ environment interaction in sesame (Sesamum indicum L.). Journal of Oilseeds Research. 22(1): 178-179.

\section{How to cite this article:}

Tushar Arun Mohanty, Umesh Kumar Singh, Satish Kumar Singh, Nitesh Kushwaha and Digvijay Singh. 2020. Study of Genetic Variability, Heritability and Genetic Advance in Sesame (Sesamum indicum L.) Genotypes. Int.J.Curr.Microbiol.App.Sci. 9(02): 347-356. doi: https://doi.org/10.20546/ijcmas.2020.902.044 